\title{
THOUGHTS ABOUT THE MENTEE-MENTOR RELATIONSHIP IN MEDICAL EDUCATION
}

\author{
Phillip Evans $^{1 \otimes}$
}

THIS ARTICLE MAY BE CITED AS: Evans P. Thoughts about the mentee-mentor relationship in medical education. Khyber Med Univ J 2018; $10(2): 65$.

66 A mentor is someone who can answer questions and give advice".' This definition is a useful starting point, but, is not the relationship between the mentor and the mentee something much more special? The mentee may have questions that are life-centred, highly personal, specific and part of a context that cannot be learned from formal teaching in classes or groups. The mentor is someone who is known to the mentee, who is trusted, respected and valued. Someone who embraces the role of loco parentis in effect a "professional parent" providing nurturing guidance to their emerging "professional child", and can address the issues that arise in the life of the mentee. Therefore, it is necessary to acknowledge a special element of "cognitive intimacy" within the relationship that can only exist if the matching of mentor and mentee is a good fit. Thus, some searching questions are raised, for example, how men can excel as mentors to women? ? $^{2}$ and is the pairing really a "one-size fits all" arrangement?

In his book ${ }^{4}$, Schön explores how professionals think in action. Acquiring both reflective and constructive thinking skills are essential objectives for a medical undergraduate. However, constructing a robust framework for thinking in a reflective and constructive way may be a significant challenge for someone who is facing an issue for the first time, particularly when the issue may be a critical event in an individual's personal or professional life..$^{5}$ This is precisely the time when an individual turns to the guidance of their mentor. It is the moment when the mentee calls on the experience and intellectual merits of their mentor. Such moments are usually unforeseen, frequently spontaneous rather than planned, and are part of the phenomenology of life. ${ }^{6}$ This sets the mentee-mentor relationship apart from the more commonly understood roles of tutor-tutee, teacher-student or clinical supervisor-trainee. They are set apart simply because the situation is not part of the formal curriculum, and cannot easily be time tabled or routinely scheduled. This association with the hidden curriculum means that an understanding of the complex nature and benefits of a mentor-mentee programme is not immediately obvious. ${ }^{7}$ However, it is generally recognised that medical schools that support mentees, through training mentors ${ }^{8}$ and promoting the relationship, develop a stronger community of professional practitioners. ${ }^{9}$

\section{REFERENCES}

1. Stenfors-Hayes T, Hult $\mathrm{H}$, Dahlgren LO. What does it mean to be a mentor in medical education? Med Teach 201 I;33(8):e423-8. DOI: I0.3109/0I42I59X.201।.586746

2. Bickel J. How Men Can Excel as Mentors of Women. Acad Med 2014 Aug;89(8):II00-2. DOI:10. 1097/ACM.00000000000003।3.
I凶 Member Editorial Board KMUj; Professor of Medical Education, Currently affiliated with The Medical University of Lublin, Poland

Email: phillipevans2008@googlemail.com

3. Beech BM, Calles-Escandon J, Hairston KG, Langdon SE, LathamSadler BA, Bell RA. Mentoring Programs for Underrepresented Minority Faculty in Academic Medical Centers: A Systematic Review of the Literature. Acad Med 20I 3 Apr;88(4):54 I-9. DOI: I 0. 1097 | ACM.0b0I3e3I828589e3.

4. Schön DA. The reflective practitioner: How professionals think in action. $1^{\text {st }}$ Edition. London. Routledge; 1992.

5. Vachon B, LeBlanc J. Effectiveness of past and current critical incident analysis on reflective learning and practice change. Med Educ 20II Sep;45(9): 894-904. DOI: I0.IIII/ j. I365-2923.20I I.04042.x.

6. Hyppolite J. Genesis and structure of Hegel's" Phenomenology of spirit". USA. Northwestern University Press; 1979.

7. Donovan A, Donovan J.Mentorship in postgraduate training programmes: views of Canadian programme directors. Med Educ 2009 Feb;43(2): 155-8. DOI: $10.1111 / /$. 1365-2923.2008.03258.x

8. Neighbour R. The inner apprentice: An awareness-centred approach to vocational training for general practice. CRC Press; 2018 Feb 6.

9. Frei $E$, Stamm M, BuddebergFischer B. Mentoring programs for medical students-a review of the PubMed literature 2000-2008. BMC Med Educ 2010 Apr 30;10(I):32. DOI: $10.1186 / 1472-$ 6920-10-32.

\section{CONFLICT OF INTEREST}

Author declared no conflict of interest GRANT SUPPORT AND FINANCIAL DISCLOSURE NIL

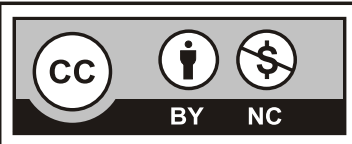

This is an Open Access article distributed under the terms of the Creative Commons Attribution-NonCommercial 2.0 Generic License. 